\title{
THE
}

\section{Career Preparations of High School Students in China, Japan, South Korea, and USA}

Jing Jian Xiao

University of Rhode Island, xiao@uri.edu

Barbara M. Newman

University of Rhode Island, bnewman@uri.edu

Follow this and additional works at: https://digitalcommons.uri.edu/hdf_facpubs

The University of Rhode Island Faculty have made this article openly available.

Please let us know how Open Access to this research benefits you.

This is a pre-publication author manuscript of the final, published article.

Terms of Use

This article is made available under the terms and conditions applicable towards Open Access

Policy Articles, as set forth in our Terms of Use.

\section{Citation/Publisher Attribution}

Xiao, Jing Jian and Newman, Barbara, Career Preparations of High School Students in China, Japan, South Korea, and USA (April 5, 2014). Available at SSRN: https://ssrn.com/abstract=2420729 or http://dx.doi.org/10.2139/ssrn.2420729

Available at: http://dx.doi.org/10.2139/ssrn.2420729

This Article is brought to you for free and open access by the Human Development and Family Science at DigitalCommons@URI. It has been accepted for inclusion in Human Development and Family Science Faculty Publications by an authorized administrator of DigitalCommons@URI. For more information, please contact digitalcommons-group@uri.edu. 


\title{
Career Preparations of High School Students in China, Japan, South Korea, and USA ${ }^{1}$
}

\author{
Jing Jian $\mathrm{Xiao}^{2} \quad$ Barbara Newman $^{3}$
}

This research brief reports descriptive statistics of an international study on high school students' career preparations. The survey was designed by a team of researchers at the China Youth and Children Research Center, Japan Youth Research Institute, Korea National Youth Policy Institute and University of Rhode Island in the US. Data were collected in representative high schools in each country in fall 2012. Among 5,191 high school students surveyed, 1,767 were from China, 1,224 from Japan, 1,295 from South Korea, and 1,024 from US. Among the total sample, about half were males and half females. The sample included students in their last three years in high school, in which $37 \%$ were sophomores, $38 \%$ juniors and $24 \%$ seniors. There were no seniors in the Korean sample. Note that in China, Japan, and South Korea, high schools have only three grades. Distribution statistics of grade and sex by country are presented in Tables 15 and 16. The following are highlights of the findings.

Plans after graduation from high school (Table 1). Following graduation from high school, most students in the total sample would like to attend a very competitive or a moderately competitive university (35\% and $36 \%$, respectively). Among them, Korean students were most likely to plan to attend both types (competitive and moderately competitive) of universities. American students were least likely to plan to attend a very competitive university and Japanese students were least likely to plan to attend a moderately competitive university. Among the whole sample, $4.8 \%$ planned to work after high school graduation without getting more education and $5.5 \%$ had never thought about what to do after graduation. Among them, Japanese students were most likely to plan to work (more than 2 times of the average) and Chinese students were most likely to report

\footnotetext{
1 Suggested citation: Xiao, J. J., \& Newman, B. (2014). Career preparations of high school students in China, Japan, South Korea, and USA. Research Brief. University of Rhode Island, Kingston, RI, USA.

2 Professor, Department of Human Development and Family Studies, University of Rhode Island, Kingston, RI, USA. Email: xiao@uri.edu.

${ }^{3}$ Professor Emeritus, Department of Human Development and Family Studies, University of Rhode Island, Kingston, RI, USA. Email: bnewman10@yahoo.com.
} 
not thinking about their plans for after graduation from high school.

With whom do students discuss their plans (Table 2)? In the total sample, students reported that mother (78\%), father (60\%), friends (55\%) and teachers (36\%) are the people with whom they discuss their plans regarding what they will do after graduation. For country variations, Korean students were most likely to report mother, Chinese father, American friends, and Japanese teachers as people to discuss their plans with.

Whether the school provides career guidance (Table 3-4). Among students surveyed, $60 \%$ reported their school provides some kind of career guidance. Japanese students were most likely while Chinese students were least likely to report so (78\% vs. 33\%). Among students reporting that their school provides some kind of career guidance, $66 \%$ said that the guidance was provided by guidance counselor and $54 \%$ by homeroom teacher. Chinese students were less likely to report guidance counselor compared to students in other countries. Japanese and Chinese students were more likely than Korean and American students to report homeroom teacher as the career guidance provider.

What type of career guidance would students like to receive (Table 5)? When students were asked what kind of career guidance they would like to receive, $70 \%$ said "Provide information and materials about a career path" and 62\% said "Help me discover my aptitudes and interests." Korean students were most likely and Japanese students were least likely to ask for information about a career path. Chinese students were most likely and Japanese students were least likely to ask for help identifying their aptitudes and interests. Interestingly, $6.3 \%$ of the total sample said "I don't expect anything from career guidance." Among them, Japanese students were most likely and Korean students were least likely to say so.

Participation in career related activities (Table 6). When students were asked about their participation in career related activities, over two fifths said they completed vocational aptitude tests (46\%), read career related materials (44\%), and attended lectures and classes on careers (43\%). About a quarter of them visited workplaces (27\%), participated in job experience programs (26\%), and attended career counseling (25\%). $8.5 \%$ said they attended vocational training. Country variations were found in these activities. For example, compared to the average, Korean students were almost twice as likely to complete vocational aptitude tests but the likelihood of Chinese students doing it is only half of the average. 
Part time job status, reasons, and benefits (Table 7-9). Among the total sample, about one fourth reported having part-time jobs in the last year. American students were twice as likely as students in three Asian countries to have part-time jobs. When asked about reasons to have a part-time job, $72 \%$ reported to earn money for personal expenses, $57 \%$ to gain working experience, $40 \%$ to improve own abilities, $32 \%$ to earn money for living expenses and tuitions. Other reasons include: to make use of spare time (26\%), to follow parents' recommendations (12\%) and to make more friends (4.3\%). For example, American students were most likely to report having a part-time job for living expenses and least likely for making use of spare time. Chinese students were most likely to report for improving ability, gaining work experience, and making more friends but least likely to report for personal expenses and parental recommendations. Students were also asked whether part-time work experience is beneficial for their career development. On a 4-point scale (1-not useful at all, 4-very useful), the average score for the whole sample was 2.76. Japanese students considered the experience most beneficial (3.06) and Korean students considered the experience least beneficial (2.29).

Perceived career preparation (Table 10). Students were asked to rate five aspects of their career preparation on 4-point scales. Scores of these aspects were summed to form the score of perceived career preparation with a range of 5-20 (the higher number implies a better preparation). The mean score for the whole sample was 13.9. Comparatively, American students had the highest mean score (15.8) and Japanese students had the lowest score (13.2), implying American students are most confident and Japanese students are least confident in perceived career preparation. Chinese and Korean students' scores were in between.

What occupations would students like to have (Table 11)? When students were asked what occupations they would like to have, the five top choices were: artist, architect, and designer (24\%), corporate manager and executive (21\%), government employee (20\%), medical doctor (20\%), and elementary, junior high, and high school teacher (19\%). Country variations were seen in these occupation choices. In comparison to the other countries, Korean students were more likely to choose teacher, artist, and government employee; American students were more likely to choose doctor; and Chinese students were more likely to choose entrepreneur as their occupations. Japanese students were least likely to choose doctor, artist, and manager; Chinese students were least likely to choose teacher; and American students were least likely to choose government employee as their 
occupations.

Who influences students' career choices (Table 12)? When students were asked who influenced their career choices most, the top five types of people mentioned by the students were mother (48\%), father (42\%), media (23\%), friends (22\%), and other family members $(21 \%)$. For country differences, Korean students were most likely to mention mother, media, and friends. Chinese students were most likely to mention father. American students were most likely to mention other family members. Japanese students were least likely to mention father, mother, other family members and media. Chinese students were least likely to mention media as having the most influence on their career choices.

Important factors for choosing a career (Table 13). Students were asked to identify factors that influenced their career choices; 11 items were asked in the survey. After exploratory factor analyses, these items were summed to three factors, practical (income, stability, flexibility, work environment, work benefits), ideological (well-suited to own capabilities and preferences, challenging, opportunities to demonstrate own abilities, contribute to society), and superficial (social status, fame) and converted to three $Z$ scores (see details of the methodology in the note of Table 13). Referring to these $Z$ scores, American students had the lowest and Korean students had the highest superficial score. In terms of practical and ideological factors, Japanese students had the lowest scores and American students had the highest scores.

Perceived purpose of work (Table 14). When asked about the value or purpose of work, over half of the whole sample provided the following purposes: to achieve happiness for the family $(55 \%)$, to make a living (55\%), and to gain self-fulfillment $(50 \%)$. Other work purposes mentioned were: to enjoy work (43\%), to contribute to society (33\%), and to be respected (17\%). American students were most likely to report all these purposes except for "gain fulfillment," which was reported most often by Chinese students. Korean students were least likely to report all of these purposes.

In conclusion, the survey highlights both similarities and differences in career planning and preparation for high school youth in the four countries.

- The majority of students aspire to attend a competitive or moderately competitive university after graduating from high school.

- $\quad$ Family members play an important role in students' career plans and aspirations. 
- Mothers are especially important for Korean youth; fathers for Chinese youth; friends for U.S. youth; and teachers for Japanese youth.

- China provides less in the way of school-based career guidance than the other three countries.

- Countries differ notably in the people who provide career guidance within the school.

- Students expressed interest in a wide range of career guidance, with a majority of students seeking help in discovering their aptitudes and interests, and learning about career paths.

- The most typical career-preparation activities were classes, aptitude tests, and reading materials. Fewer students had "hands-on" work experiences or vocational training.

- The majority of students have not had a part-time job; however many more students in the U.S. have had a part time job than in the other countries. Among Chinese students, the important reason to have a part-time job is to improve their abilities and to gain work experience. For U.S. students, the most important reason is to earn money for personal expenses.

- Even though Japanese students are unlikely to have a part-time job, they are most likely to agree that the experience is beneficial for career development.

- $\quad$ Students in the U.S. have the most confidence in their career preparation; Chinese students have the least confidence.

- Desired careers vary across countries. $30 \%$ of U.S. students would like to be a medical doctor; $32 \%$ of Chinese students would like to be an entrepreneur; $30 \%$ of Korean students would like to be an artist, architect, or designer; and $20 \%$ of Japanese youth would like to be a government employee.

- When considering the reasons for choosing a career, status and fame were more important for the Korean students than for students in the other countries; practical and ideological reasons were more important for the U.S. students than for students in the other countries. 
Acknowledgements: We thank the Provost Office of the University of Rhode Island, College of Human Science and Services, and Department of Human Development for sponsoring a research meeting held at URI in summer 2012 in which the survey was discussed and designed. The following researchers participated in the meeting: Sun-Young Ahn (Korea National Youth Policy Institute), Xia Hu (Japan Youth Research Institute), Barbara Newman (URI), Hongyan Sun (China Youth and Children Research Center), Jing Jian Xiao (URI), Chunying Zhang (China Youth and Children Research Center). Xia Hu provided the data set used for this research brief. Indrawati Liauw (URI) was a translator for the meeting. 
Table 1: After Graduation Plan (Q1)

\begin{tabular}{lrrrrr}
\hline & China & Japan & Korea & USA & Total \\
\hline Apply to a very competitive university. & $35.90 \%$ & $29.40 \%$ & $42.00 \%$ & $28.10 \%$ & $34.50 \%$ \\
Apply to a moderately competitive. & $36.90 \%$ & $32.80 \%$ & $38.40 \%$ & $37.90 \%$ & $36.50 \%$ \\
Apply to less competitive (i.e. easy to get into) universities. & $9.80 \%$ & $5.60 \%$ & $1.90 \%$ & $7.10 \%$ & $6.40 \%$ \\
Study abroad. & $4.50 \%$ & $1.00 \%$ & $1.90 \%$ & $2.80 \%$ & $2.70 \%$ \\
Apply to a 2 or 3-year colleges. & $3.40 \%$ & $3.00 \%$ & $5.60 \%$ & $13.80 \%$ & $5.70 \%$ \\
Apply to technical schools. & $1.60 \%$ & $11.30 \%$ & $1.50 \%$ & $2.20 \%$ & $3.90 \%$ \\
Work after high school graduation. & $1.40 \%$ & $12.50 \%$ & $2.40 \%$ & $4.30 \%$ & $4.80 \%$ \\
I have not thought about what to do after high school. & $6.50 \%$ & $4.50 \%$ & $6.30 \%$ & $3.70 \%$ & $5.50 \%$ \\
N & 1758 & 1220 & 1290 & 970 & 5238 \\
\hline
\end{tabular}

Table 2 With Whom to Discuss Plans After Graduation (Q2)

\begin{tabular}{lrrrrr}
\hline & China & Japan & Korea & USA & Total \\
\hline Father (male guardian) & $74.20 \%$ & $46.00 \%$ & $54.40 \%$ & $61.00 \%$ & $60.30 \%$ \\
Mother (female guardian) & $77.80 \%$ & $75.90 \%$ & $80.40 \%$ & $79.70 \%$ & $78.30 \%$ \\
Friends & $48.00 \%$ & $59.30 \%$ & $49.60 \%$ & $68.10 \%$ & $54.90 \%$ \\
School teachers & $37.70 \%$ & $44.60 \%$ & $27.60 \%$ & $35.10 \%$ & $36.30 \%$ \\
Elder siblings & $26.10 \%$ & $21.30 \%$ & $21.90 \%$ & $26.90 \%$ & $24.10 \%$ \\
Older schoolmates & $10.60 \%$ & $21.70 \%$ & $5.10 \%$ & $18.80 \%$ & $13.40 \%$ \\
Tutors & $6.40 \%$ & $18.70 \%$ & $26.60 \%$ & $5.40 \%$ & $14.00 \%$ \\
Grandparents & $6.70 \%$ & $4.30 \%$ & $1.40 \%$ & $28.60 \%$ & $9.10 \%$ \\
Other & $6.50 \%$ & $6.30 \%$ & $2.00 \%$ & $20.60 \%$ & $8.10 \%$ \\
I don't have anyone to discuss with & $4.50 \%$ & $4.50 \%$ & $3.50 \%$ & $3.10 \%$ & $4.00 \%$ \\
N & 1767 & 1220 & 1295 & 1024 & 5310 \\
\hline
\end{tabular}


Table 3 Whether The School Provides Career Guidance (Q6)

\begin{tabular}{lrrrrr}
\hline & China & \multicolumn{1}{c}{ Japan } & \multicolumn{1}{c}{ Korea } & \multicolumn{1}{c}{ USA } & \multicolumn{1}{c}{ Total } \\
\hline Yes & $33.10 \%$ & $78.20 \%$ & $72.30 \%$ & $68.80 \%$ & $60.00 \%$ \\
No & $23.10 \%$ & $2.40 \%$ & $14.80 \%$ & $11.00 \%$ & $13.90 \%$ \\
Don't know & $43.80 \%$ & $19.40 \%$ & $12.90 \%$ & $20.20 \%$ & $26.10 \%$ \\
N & 1751 & 1221 & 1295 & 1009 & 5276 \\
\hline
\end{tabular}

Table 4 Who Provides Career Guidance in School (Q6-1)

\begin{tabular}{lrrrrr}
\hline & China & Japan & Korea & USA & Total \\
\hline Guidance counselor & $24.80 \%$ & $72.30 \%$ & $79.50 \%$ & $74.10 \%$ & $66.10 \%$ \\
Homeroom teacher & $76.70 \%$ & $83.40 \%$ & $31.10 \%$ & $25.90 \%$ & $54.10 \%$ \\
Counselor/ School Psychologist & $21.90 \%$ & $1.40 \%$ & $13.10 \%$ & $32.30 \%$ & $15.40 \%$ \\
Social worker & $6.40 \%$ & $0.50 \%$ & $1.80 \%$ & $2.40 \%$ & $2.40 \%$ \\
Other & $7.40 \%$ & $2.50 \%$ & $1.30 \%$ & $16.90 \%$ & $6.20 \%$ \\
$\mathrm{~N}$ & 580 & 955 & 936 & 694 & 3165 \\
\hline
\end{tabular}

Table 5 What Kind of Career Guidance in School Would Students Want to Receive (Q7)

\begin{tabular}{lrrrrc}
\hline & China & Japan & Korea & USA & Total \\
\hline Help me discover my aptitudes and interests. & $72.90 \%$ & $48.60 \%$ & $64.60 \%$ & $55.30 \%$ & $61.90 \%$ \\
Provide information and materials about a career path. & $69.20 \%$ & $63.20 \%$ & $75.40 \%$ & $71.50 \%$ & $69.70 \%$ \\
Give me information and techniques that I can use immediately & $45.10 \%$ & $27.30 \%$ & $36.80 \%$ & $52.30 \%$ & $40.40 \%$ \\
$\quad$ when I get a job. & & & & & \\
Opportunities for internship. & $49.60 \%$ & $22.30 \%$ & $31.70 \%$ & $62.30 \%$ & $41.40 \%$ \\
Opportunities to see workplaces. & $37.10 \%$ & $23.00 \%$ & $49.30 \%$ & $54.60 \%$ & $40.20 \%$ \\
Opportunities to participate in discussions about specific & $32.30 \%$ & $18.90 \%$ & $27.20 \%$ & $45.00 \%$ & $30.40 \%$ \\
$\quad$ careers. & & & & & \\
Opportunities to talk to professionals in my community. & $41.40 \%$ & $19.20 \%$ & $54.30 \%$ & $54.70 \%$ & $42.00 \%$ \\
Opportunities to consult teachers about my career path. & $34.50 \%$ & $26.40 \%$ & $30.10 \%$ & $25.00 \%$ & $29.70 \%$ \\
Other & $5.00 \%$ & $0.70 \%$ & $0.30 \%$ & $7.20 \%$ & $3.30 \%$ \\
I don't expect anything from career guidance. & $5.70 \%$ & $10.70 \%$ & $3.80 \%$ & $5.20 \%$ & $6.30 \%$ \\
N & 1767 & 1224 & 1295 & 1024 & 5310 \\
\hline
\end{tabular}


Table 6 Participation of Career Related Activities (Q8)

\begin{tabular}{lccccc}
\hline & China & Japan & Korea & USA & Total \\
\hline Lectures or classes on careers & $19.50 \%$ & $53.00 \%$ & $59.80 \%$ & $48.20 \%$ & $42.60 \%$ \\
Vocational aptitude tests & $12.70 \%$ & $61.10 \%$ & $88.60 \%$ & $30.30 \%$ & $46.00 \%$ \\
Career counseling & $12.50 \%$ & $10.30 \%$ & $48.70 \%$ & $30.90 \%$ & $24.50 \%$ \\
Job experience programs & $15.60 \%$ & $42.40 \%$ & $20.60 \%$ & $32.60 \%$ & $26.30 \%$ \\
Vocational training & $6.40 \%$ & $7.10 \%$ & $7.20 \%$ & $15.40 \%$ & $8.50 \%$ \\
Reading career-related books or magazines & $27.20 \%$ & $53.00 \%$ & $54.30 \%$ & $50.50 \%$ & $44.30 \%$ \\
Workplace visits & $18.10 \%$ & $44.20 \%$ & $13.60 \%$ & $39.90 \%$ & $27.20 \%$ \\
N & 1743 & 1218 & 1295 & 1002 & 5256 \\
\hline
\end{tabular}

Table 7 Having a Part-time Job Last Year (Q9)

\begin{tabular}{lrrrrr}
\hline & China & Japan & \multicolumn{1}{l}{ Korea } & \multicolumn{1}{l}{ USA } & \\
\hline Yes & $21.40 \%$ & $20.60 \%$ & $16.70 \%$ & $44.60 \%$ & $24.50 \%$ \\
No & $78.60 \%$ & $79.40 \%$ & $83.30 \%$ & $55.40 \%$ & $75.50 \%$ \\
N & 1742 & 1221 & 1295 & 1010 & 5268 \\
\hline
\end{tabular}

Table 8 Reasons for Having a Part-time Job (Q9-1)

\begin{tabular}{lrrrrr}
\hline & China & Japan & \multicolumn{1}{c}{ Korea } & USA & \multicolumn{1}{c}{ Total } \\
\hline To earn money for living expenses and tuition fees. & $29.30 \%$ & $35.10 \%$ & $19.90 \%$ & $36.90 \%$ & $31.50 \%$ \\
To earn money for personal expenses. & $47.00 \%$ & $71.10 \%$ & $94.00 \%$ & $81.80 \%$ & $71.90 \%$ \\
To improve my abilities. & $81.50 \%$ & $19.50 \%$ & $18.50 \%$ & $26.20 \%$ & $39.60 \%$ \\
To gain work experiences. & $62.40 \%$ & $56.20 \%$ & $53.20 \%$ & $55.60 \%$ & $57.30 \%$ \\
To make use of my spare time. & $30.40 \%$ & $19.10 \%$ & $44.00 \%$ & $18.00 \%$ & $26.10 \%$ \\
My parents (relatives or friends) recommended this. & $7.30 \%$ & $7.60 \%$ & $20.40 \%$ & $14.20 \%$ & $11.90 \%$ \\
To make more friends. & $10.50 \%$ & $1.20 \%$ & $0.90 \%$ & $2.40 \%$ & $4.30 \%$ \\
Other & $3.20 \%$ & $6.00 \%$ & $0.00 \%$ & $24.20 \%$ & $11.60 \%$ \\
N & 372 & 251 & 216 & 450 & 1289 \\
\hline
\end{tabular}


Table 9 Whether Work Experience Beneficial for Career Development (Q9-2)

\begin{tabular}{lcrc} 
& Mean & Std. Deviation & \multicolumn{1}{l}{$N$} \\
\hline China & 2.8859 & 0.87223 & 368 \\
Japan & 3.0637 & 0.84612 & 251 \\
Korea & 2.2864 & 0.86702 & 206 \\
USA & 2.6792 & 0.95129 & 371 \\
Total & 2.7559 & 0.92601 & 1196 \\
\hline
\end{tabular}

Note: based on a 4-point scale, 4-Very useful; 3-Somewhat useful; 2-Not very useful; 1-Not useful at all. The variable was reverse coded from the original data.

Table 10 Perceived Career Preparation (Q10)

\begin{tabular}{|c|c|c|c|c|c|c|}
\hline & China & Japan & Korea & USA & Total & $\mathrm{N}$ \\
\hline I know my abilities and aptitude. & 3.0739 & 2.5675 & 2.7668 & 3.2832 & 2.9210 & 5279 \\
\hline I have clear goals for my future. & 2.9217 & 2.7840 & 2.7745 & 3.2710 & 2.9199 & 5279 \\
\hline $\begin{array}{l}\text { I have knowledge about the occupation that I want to } \\
\text { have. }\end{array}$ & 2.5765 & 2.5148 & 2.7697 & 3.2020 & 2.7278 & 5268 \\
\hline $\begin{array}{l}\text { I research and collect information for the options } \\
\text { after high school. }\end{array}$ & 2.6494 & 2.6194 & 2.5719 & 2.9608 & 2.6823 & 5269 \\
\hline I am interested in current employment opportunities. & 2.4665 & 2.6907 & 2.5236 & 3.0489 & 2.6430 & 5277 \\
\hline Total score & 13.6851 & 13.1741 & 13.4073 & 15.7917 & 13.8929 & 5249 \\
\hline
\end{tabular}

Note: based on a 4-point scale, 4-Very useful; 3-Somewhat useful; 2-Not very useful; 1-Not useful at all. The variable was reverse coded from the original data. 
Table 11 Occupations Students Would Like to Have (Q11)

\begin{tabular}{|c|c|c|c|c|c|}
\hline & China & Japan & Korea & USA & Total \\
\hline Medical doctor (e.g., physician, dentist) & $25.40 \%$ & $6.50 \%$ & $15.70 \%$ & $30.50 \%$ & $19.60 \%$ \\
\hline Legal profession (e.g., prosecutor, judge) & $21.70 \%$ & $4.20 \%$ & $10.30 \%$ & $11.90 \%$ & $13.00 \%$ \\
\hline College professor, researcher & $16.20 \%$ & $7.30 \%$ & $18.10 \%$ & $10.00 \%$ & $13.40 \%$ \\
\hline Elementary, junior high and high school teacher & $14.70 \%$ & $18.20 \%$ & $28.60 \%$ & $16.60 \%$ & $19.20 \%$ \\
\hline Journalist, reporter, editor & $14.70 \%$ & $6.80 \%$ & $14.10 \%$ & $13.00 \%$ & $12.40 \%$ \\
\hline $\begin{array}{l}\text { Artist, architect, designer (e.g. fashion, interior design, graphic } \\
\text { design, CG) }\end{array}$ & $26.10 \%$ & $12.80 \%$ & $30.00 \%$ & $24.90 \%$ & $24.00 \%$ \\
\hline $\begin{array}{l}\text { Profession in financial field (e.g. accountant, banker, or stock } \\
\text { broker) }\end{array}$ & $21.6 \%$ & $5.20 \%$ & $20.2 \%$ & $8.8 \%$ & $15.0 \%$ \\
\hline Mechanic, electrician, mechanical/ electrical engineer & $8.20 \%$ & $8.90 \%$ & $16.70 \%$ & $15.60 \%$ & $11.90 \%$ \\
\hline IT professional (e.g. system engineer, programmer) & $12.6 \%$ & $8.1 \%$ & $14.4 \%$ & $8.9 \%$ & $11.3 \%$ \\
\hline Technical job in construction, civil engineering, surveying & $10.40 \%$ & $4.20 \%$ & $8.80 \%$ & $7.80 \%$ & $8.10 \%$ \\
\hline Technician in agriculture and fisheries & $5.40 \%$ & $3.80 \%$ & $3.50 \%$ & $2.90 \%$ & $4.10 \%$ \\
\hline Corporate manager, executive & $27.60 \%$ & $11.60 \%$ & $27.30 \%$ & $12.70 \%$ & $21.00 \%$ \\
\hline Corporate sales representative & $8.40 \%$ & $9.40 \%$ & $12.70 \%$ & $7.00 \%$ & $9.40 \%$ \\
\hline Government employee & $21.10 \%$ & $20.30 \%$ & $24.90 \%$ & $9.80 \%$ & $19.70 \%$ \\
\hline General office clerk & $5.60 \%$ & $10.70 \%$ & $19.20 \%$ & $2.10 \%$ & $9.40 \%$ \\
\hline Food related profession such as cook, chef, pastry chef & $14.00 \%$ & $8.70 \%$ & $16.30 \%$ & $14.00 \%$ & $13.40 \%$ \\
\hline $\begin{array}{l}\text { Profession in beauty industry such as hair stylist, barber, hair } \\
\qquad \& \text { make up artist }\end{array}$ & $6.20 \%$ & $8.70 \%$ & $6.30 \%$ & $9.40 \%$ & $7.40 \%$ \\
\hline Animal related profession such as veterinarian, groomer. & $6.50 \%$ & $5.20 \%$ & $10.70 \%$ & $13.10 \%$ & $8.50 \%$ \\
\hline $\begin{array}{l}\text { Welfare profession such as caseworker, care worker, } \\
\text { caregiver }\end{array}$ & $3.40 \%$ & $6.90 \%$ & $10.40 \%$ & $4.00 \%$ & $6.00 \%$ \\
\hline Sales clerk & $3.60 \%$ & $10.60 \%$ & $4.30 \%$ & $2.60 \%$ & $5.20 \%$ \\
\hline Police officer or military personnel & $16.50 \%$ & $5.40 \%$ & $15.40 \%$ & $15.80 \%$ & $13.50 \%$ \\
\hline Professional athlete, singer, actor, actress & $14.0 \%$ & $7.0 \%$ & $16.2 \%$ & $19.2 \%$ & $14.0 \%$ \\
\hline Entrepreneur & $31.90 \%$ & $6.00 \%$ & $12.00 \%$ & $19.00 \%$ & $18.60 \%$ \\
\hline Freelance part -time worker & $16.60 \%$ & $1.40 \%$ & $6.90 \%$ & $3.10 \%$ & $8.10 \%$ \\
\hline Others & $5.5 \%$ & $20.9 \%$ & $12.4 \%$ & $25.4 \%$ & $14.6 \%$ \\
\hline
\end{tabular}


Table 12 Which People Have the Most Influence on Career Choice (Q12)

\begin{tabular}{lrrrrr}
\hline & China & Japan & \multicolumn{1}{l}{ Korea } & \multicolumn{1}{l}{ USA } \\
\hline Father (male guardian) & $52.00 \%$ & $25.70 \%$ & $43.60 \%$ & $44.00 \%$ & $42.40 \%$ \\
Mother (female guardian) & $54.40 \%$ & $30.40 \%$ & $57.50 \%$ & $47.10 \%$ & $48.20 \%$ \\
Family members besides parents & $20.00 \%$ & $11.80 \%$ & $25.20 \%$ & $30.40 \%$ & $21.40 \%$ \\
Teachers & $15.80 \%$ & $13.80 \%$ & $17.60 \%$ & $13.70 \%$ & $15.40 \%$ \\
Older students at school or former graduate from high school & $7.60 \%$ & $9.30 \%$ & $2.90 \%$ & $6.30 \%$ & $6.60 \%$ \\
Friends & $24.10 \%$ & $13.50 \%$ & $29.80 \%$ & $18.60 \%$ & $22.00 \%$ \\
Idols, stars & $15.90 \%$ & $3.40 \%$ & $3.30 \%$ & $6.20 \%$ & $8.10 \%$ \\
Media such as news papers, magazines, internet & $10.40 \%$ & $25.80 \%$ & $46.20 \%$ & $12.70 \%$ & $23.10 \%$ \\
Other & $3.60 \%$ & $13.30 \%$ & $22.30 \%$ & $18.90 \%$ & $13.40 \%$ \\
I'm not influenced by anybody or anything & $16.20 \%$ & $28.10 \%$ & $10.00 \%$ & $12.90 \%$ & $16.80 \%$ \\
$\mathrm{~N}$ & 1767 & 1224 & 1295 & 1024 & 5310 \\
\hline
\end{tabular}

Table 13 Important Factors For Choosing a Career (Q13)

\begin{tabular}{lcccccc}
\hline & China & Japan & Korea & USA & Total & $\mathrm{N}$ \\
\hline Superficial & .1218 & -.1244 & .2225 & -.3524 & .0000 & 5225 \\
Practical & -.1244 & -.1395 & -.0054 & .3923 & .0000 & 5188 \\
Ideological & -.1072 & -.1227 & .0400 & .2930 & .0000 & 5213 \\
\hline
\end{tabular}

Note: Statistics in the table are Z scores. The positive number means above the average and the negative number means below the average of the total sample. Factor analysis was conducted among 11 items on the question asking important factors for choosing a career and three factors were identified: practical (income, stability, flexibility, work environment, work benefits), ideological (well-suited to own capabilities and preferences, challenging, opportunities to demonstrate own abilities, contribute to society), and superficial (social status, fame) factors to chose a career. Each of the factors was summed by the corresponding variables. For example, the scores of the five variables relevant to practical factors were summed and then convert to $Z$ score. The same procedure was applied to the other two factors. 
Table 14 Perceived Purposes of Working (Q15)

\begin{tabular}{lrrrrr}
\hline & China & Japan & \multicolumn{2}{c}{ Korea } & USA \\
\hline To achieve happiness for my family & $75.80 \%$ & $52.10 \%$ & $23.20 \%$ & $63.40 \%$ & $55.10 \%$ \\
To gain self-fulfillment & $62.30 \%$ & $51.00 \%$ & $25.90 \%$ & $59.70 \%$ & $50.30 \%$ \\
To contribute to society & $36.70 \%$ & $38.80 \%$ & $6.10 \%$ & $51.20 \%$ & $32.50 \%$ \\
To be respected & $17.00 \%$ & $8.50 \%$ & $4.90 \%$ & $44.20 \%$ & $17.30 \%$ \\
To enjoy work & $42.30 \%$ & $43.00 \%$ & $28.80 \%$ & $62.00 \%$ & $43.00 \%$ \\
To make a living & $56.30 \%$ & $58.90 \%$ & $31.70 \%$ & $77.50 \%$ & $55.00 \%$ \\
I don't know & $5.20 \%$ & $4.70 \%$ & $3.80 \%$ & $3.10 \%$ & $4.30 \%$ \\
N & 1767 & 1224 & 1295 & 1024 & 5310 \\
\hline
\end{tabular}

Table 15 Gender (F1)

\begin{tabular}{lrrrrr}
\hline & \multicolumn{1}{c}{ China } & \multicolumn{1}{c}{ Japan } & \multicolumn{1}{l}{ Korea } & \multicolumn{1}{l}{ USA } & \multicolumn{1}{l}{ Total } \\
\hline Male & $44.8 \%$ & $48.2 \%$ & $53.6 \%$ & $47.0 \%$ & $48.2 \%$ \\
Female & $55.1 \%$ & $51.8 \%$ & $46.4 \%$ & $48.3 \%$ & $50.9 \%$ \\
Missing & $.1 \%$ & $0.0 \%$ & $0.0 \%$ & $4.7 \%$ & $.9 \%$ \\
$\mathrm{~N}$ & 1767 & 1224 & 1295 & 1024 & 5195 \\
\hline
\end{tabular}

Table 16 School Year (F2)

\begin{tabular}{lrrrrr}
\hline & \multicolumn{1}{l}{ China } & Japan & \multicolumn{1}{l}{ Korea } & \multicolumn{1}{l}{ USA } & \multicolumn{1}{l}{ Total } \\
\hline Sophomore & $35.1 \%$ & $35.9 \%$ & $50.0 \%$ & $26.9 \%$ & $37.3 \%$ \\
Junior & $37.9 \%$ & $38.7 \%$ & $50.0 \%$ & $22.5 \%$ & $38.1 \%$ \\
Senior & $26.9 \%$ & $25.4 \%$ & $0.0 \%$ & $46.3 \%$ & $23.7 \%$ \\
Missing & $.1 \%$ & $0.0 \%$ & $0.0 \%$ & $4.4 \%$ & $.9 \%$ \\
$\mathrm{~N}$ & 1767 & 1224 & 1295 & 1024 & 5195 \\
\hline
\end{tabular}

Note: In China, Japan, and South Korea, high schools have only three grades. Then senior=third year, junior=second year, and sophomore=first year in high school in these countries. 